\title{
A Condição de Aluno- Professor de Língua Inglesa em Discussão: estágio, identidade e agência
}

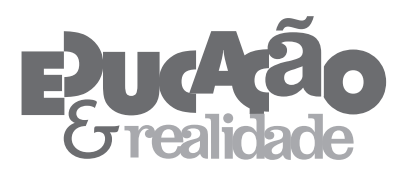

\author{
Clarissa Menezes Jordão' \\ Édina Aparecida Cabral Bührer' \\ 'Universidade Federal do Paraná (UFPR), Curitiba/PR - Brasil
}

RESUMO - A Condição de Aluno-Professor de Língua Inglesa em Discussão: estágio, identidade e agência. O Estágio Curricular Supervisionado envolve situações conflitantes relacionadas à condição do licenciando como aprendiz e professor, em especial no caso da licenciatura em língua inglesa. Este texto aborda o posicionamento dos licenciandos ora como alunos, ora como professores, e os conflitos que esta posição híbrida, em não sendo reconhecida como tal, pode ocasionar. A partir da leitura de teorias póscoloniais como as de Bhabha, Hall e Derrida, concluímos que este espaço, quando explicitado como um lócus de enunciação que coloca o aluno-professor em um lugar de hibridização, oferece uma oportunidade de exercício de agência aos sujeitos nesta etapa de sua formação.

Palavras-chave: Aluno-Professor. Estágio. Língua Inglesa. Agência. Hibridização.

ABSTRACT - Debating the English Language Student-Teacher Condition: practicum, identity and agency. The practicum is a stage in teacher formal education usually surrounded by conflicting situations, especially in regard to the positioning of the student-teacher sometimes as a learner and other times as a teacher, particularly when working with teachers of English as a Foreign Language. This text focuses on this process of positioning student-teachers and the conflicts such positioning brings, discussing some of the ideas put forward by Bhabha, Hall and Derrida and advancing the possibility that the practicum, when openly treated as a hybrid locus, can bring forward student-teachers agencies that can improve their building of professional identities.

Keywords: Student-Teacher. Practicum. English Language. Agency. Hybridization.

Educação \& Realidade, Porto Alegre, v. 38, n. 2, p. 669-682, abr./jun. 2013. 
A Condição de Aluno-Professor de Língua Inglesa em Discussão

\section{Contextualizando a Discussão}

Primeiramente faz-se necessário informar ao leitor que esta discussão integra um projeto mais amplo de pesquisa que procura discutir a formação pré-serviço do professor de língua inglesa a partir do estágio curricular supervisionado. Sabendo de antemão que não é possível dar conta da amplitude do tema nas poucas linhas deste texto, é preciso que o leitor tenha conhecimento que o objetivo central do artigo é apresentar uma visão geral do assunto, com a finalidade de expor uma das complexidades que envolvem o aluno-professor durante o estágio curricular supervisionado, ou seja, a sua condição simultânea de aprendente e ensinante ${ }^{1}$ de uma língua estrangeira. Assim, a escrita deste artigo foi dividida em três partes. Na primeira parte trata-se do estágio curricular supervisionado em relação ao lugar ocupado pelo aluno-professor de língua inglesa; em seguida, relaciona-se o lugar do aluno-professor no estágio curricular supervisionado com noções de identidade, différan$c e^{2}$ e ensino bancário a partir da leitura de Stuart Hall, Derrida e Paulo Freire, e num terceiro momento discutem-se os conceitos de hibridização, terceiro espaço e agência na perspectiva dos estudos de Homi Bhabha e seus desdobramentos no processo identitário do professor em formação.

\section{O Estágio Supervisionado e a Condição de Aluno- Professor de Língua Inglesa}

O Estágio Curricular Supervisionado configura-se como um momento de extrema importância nos cursos de licenciaturas, principalmente no curso de Letras. Este momento da formação do aluno-professor esteve por muito tempo relegado a um segundo plano, ocupando um lugar de subalternidade em relação às disciplinas consideradas teóricas, pois

Um dos problemas centrais dos cursos de formação é a falta de articulação entre os chamados conteúdos pedagógicos e os conteúdos a serem ensinados. Isso se mostra muito nitidamente nos cursos de licenciatura, compostos por dois grupos de disciplinas. Em um grupo, estão as disciplinas de formação específica na área e, no outro, estão as disciplinas de formação geral e pedagógica. Geralmente, esses dois grupos de disciplinas são desenvolvidos de forma desarticulada e, até mesmo, contraditória. Afirmase, por exemplo, uma concepção de ensino e de aprendizagem à luz da ideia de resolução de problemas, enquanto nas aulas das disciplinas do primeiro grupo prevalece uma prática baseada, unicamente, na transmissão de conhecimentos descontextualizados, sem participação do aluno. Pode-se dizer, também, que, em muitas instituicões formadoras, há um certo desprestígio do segundo grupo de disciplinas e dos professores que trabalham 
com elas (Diretrizes para Formação Inicial de Professores da Educação Básica, em Cursos de Nível Superior. Apêndices, 2000, p. 526).

No entanto, a partir da Lei das Diretrizes e Bases da Educação Nacional (LDB) n. 9394/96 e das Diretrizes Curriculares Nacionais para a Formação de Professores da Educação Básica, em nível superior, curso de licenciatura, de graduação plena (Brasil, 2002a; 2002b) criou-se a possibilidade de olhar para este momento da formação com mais atenção, trazendo-o para um nível de discussão não mais como simplesmente uma disciplina (Cury, 1996), tampouco como uma disciplina desprestigiada, qualificação que tem recebido em alguns contextos educacionais em relação às disciplinas de cunho teórico, conforme apontado anteriormente. O nível de reflexão proposto para este componente curricular concebe-o como um espaço-tempo fundamental na formação do professor.

Este novo olhar, no entanto, ainda é ofuscado pela névoa que paira em relação ao cunho tecnicista que existe na legislação em torno do entendimento de competências do professor e da situação de desprestígio do estágio em relação à matriz curricular, pois o "[...] estágio, conforme escrito nas resoluções continua separado tanto das atividades práticas quanto das denominadas científico-culturais. Portanto, nem prática, nem teoria; apenas treinamento de competências e aprendizagens de práticas modelares" (Pimenta e Lima, 2004, p. 87). Este isolamento pode ser observado quando as diretrizes quantificam e separam o estágio dos conteúdos curriculares de natureza científico-culturais e das atividades acadêmico-científico-culturais deixando-o, conforme discutem Pimenta e Lima (2004) fora dos conteúdos e das atividades.

Embora questões como estas ainda não permitam que o estágio curricular supervisionado possa realmente conquistar um lugar de importância na formação do professor de línguas, não se pode negar que os documentos oficiais, mencionados anteriormente, colocaram o estágio e a prática em destaque. Tal posicionamento pode ser percebido na produção de pesquisas em torno dos acontecimentos que envolvem o estágio e a prática no interior dos cursos de Letras nos últimos anos (Xavier, 2004; Gimenez, 2004; Barcelos; Batista; Andrade, 2004; Fernandes, 2005; Rigolon, 2006; Rodrigues, 2007; Daniel, 2009; Cabral-Bührer, 2010), pelo menos no que se refere ao ensino de língua inglesa. Certamente que este movimento em torno do estágio também está relacionado à necessidade de rediscutir a formação de professores, considerando os resultados de pesquisas nos anos de 1990, os quais mostraram um professor altamente influenciado pelo mercado editorial e pelo ensino da linguagem como um produto de análise linguística (Gil, 2005). No entanto, acredito que o interesse maior da academia sobre o estágio e a prática como componentes curriculares na atualidade deve-se em grande parte a importância dada pela legislação a estes momentos da formação. Se não fosse a lei das Diretrizes e Bases da Educação Nacio- 
nal, n. 9394/96, enfatizando a importância da formação de professores estipulando que "[...] a formação docente, exceto para a educação superior, incluirá prática de ensino de, no mínimo, trezentas horas" (Saviani, 1997, p. 182), bem como, as Diretrizes Curriculares para a Formação de Professores da Educação Básica quando amplia a carga horária da formação de professores enfatizando que:

\begin{abstract}
Art. $1^{\circ}$ A carga horária dos cursos de Formação de Professores da Educação Básica, em nível superior, em curso de licenciatura, de graduação plena, será efetivada mediante a integralização de, no mínimo, 2800 (duas mil e oitocentas) horas, nas quais a articulação teoria-prática garanta, nos termos dos seus projetos pedagógicos, as seguintes dimensões dos componentes comuns:

I - 400 (quatrocentas) horas de prática como componente curricular, vivenciadas ao longo do curso;

II - 400 (quatrocentas) horas de estágio curricular supervisionado a partir do início da segunda metade do curso; III - 1800 (mil e oitocentas) horas de aulas para os conteúdos curriculares de natureza científico-cultural;

IV - 200 (duzentas) horas para outras formas de atividades acadêmico-científico-culturais.

Parágrafo único. Os alunos que exerçam atividade docente regular na educação básica poderão ter redução da carga horária do estágio curricular supervisionado até o máximo de 200 (duzentas) horas (Brasil, 2002b).
\end{abstract}

Certamente os estudos em torno do estágio, da prática e da própria formação de professores, em seu âmbito geral, não estariam no patamar elevado de discussões que se encontram no momento atual; um nível que procura enfatizar o lugar da prática e do estágio como fundamentais na formação profissional do professor da Educação Básica.

Esta ênfase pode ser percebida por meio das pesquisas recentes em torno da formação inicial de professores que mostraram, entre outras questões, os problemas e dificuldades enfrentadas pelo alunoprofessor durante a prática de ensino e do estágio supervisionado. Entre as pesquisas nesta área ressalto o trabalho de Gimenez (2004) e de Barcelos, Batista e Andrade (2004). De acordo com as autoras, embora sob diferentes perspectivas teóricas, os alunos-professores enfrentam dificuldades em torno dos seus lugares como alunos e como professores de língua inglesa durante o processo de formação nos cursos de Letras. Para Gimenez (2004) existe uma situação de ambiguidade de papéis dos alunos-professores, que ora são posicionados como alunos ora como professores. Estes posicionamentos ocorrem em grande parte em função do domínio da língua, isto é, segundo a autora, com base na pesquisa de Ortenzi, Mateus e Reis (2002), embora o curso de Letras volte-se para a formação de professores, para a grande maioria dos licenciandos, o curso de Letras não é a primeira opção.

Quando o é, a escolha está estritamente vinculada à aprendizagem da língua estrangeira. Deste modo, os alu- 
nos identificam-se primeiramente como aprendizes da língua (no caso da dupla licenciatura), para depois se darem conta de que serão professores. Isso pode significar que o processo de transição para ser professor pode ser mais demorado (Gimenez, 2004, p. 176).

Desta forma muitos licenciandos não se veem como professores, mas sim como aprendizes de Língua Inglesa.

De acordo com Gimenez (2004), o fato de o domínio da Língua Inglesa não ser pré-requisito para a entrada do aluno na graduação faz com que o desenvolvimento da proficiência linguística dos alunos seja fortemente enfatizado nos anos iniciais do curso; assim, os alunos passam a ser tratados como aprendizes da língua durante grande parte do curso, levando-os a ver a si mesmos como alunos e a encontrar dificuldade de se posicionarem como professores.

Numa visão semelhante, Barcelos, Batista e Andrade (2004) discutem as expectativas e dificuldades dos licenciandos a partir da preocupação demonstrada por suas alunas-professoras com a formação recebida e com o despreparo e insegurança percebidas pelas próprias alunas-professoras para lecionar inglês. Quando estas alunas-professoras apresentaram este tipo de preocupação não haviam ainda passado pela experiência de estágio e nem assistido a aulas de Prática de Ensino. De acordo com a pesquisa realizada pelas referidas autoras, sobre as expectativas e dificuldades das alunas-professoras, dois momentos diferentes foram relatados. Um momento anterior às aulas de Prática de Ensino e da experiência de estágio e um posterior. No primeiro momento as alunas posicionaram-se como alunas porque não se sentiam aptas a ensinar a língua inglesa, pois segundo suas crenças "para ser professor é necessário ter o domínio da Língua Inglesa. Além disso, elas acreditam que um bom professor de inglês deve ter um excelente desempenho linguístico" (Barcelos; Batista; Andrade, 2004, p. 18). Já no segundo momento, conforme enfatizam as pesquisadoras, "[...] as dificuldades citadas então se referiram ao mercado de trabalho e as condições de ensino em escola pública. Os alunos já pareciam ver-se como futuros professores, aspecto este negligenciado no primeiro momento, quando esses alunos ainda se viam como alunos" (Barcelos; Batista; Andrade, 2004, p. 21). É importante perceber, nestes dois trabalhos de pesquisa, propostos por Gimenez e Barcelos, Batista e Andrade, a condição de aluno-professor durante o curso de Letras, mais precisamente no contato com o estágio. O que se compreende nestas duas situações são os posicionamentos do professor pré-serviço durante o curso de Letras, ora como aluno e ora como professor de língua.

Estas posições são analisadas no presente texto a partir de três aspectos. Primeiro, o fato de estes posicionamentos apresentarem-se aos alunos dentro de uma condição de oposição, de binaridade; segundo, analisaremos tais posicionamentos na perspectiva da différence e da invocação de outros signos no processo de construção de sentidos para 
tais posições e, terceiro, examinaremos a importância da superação da binaridade aluno-professor na perspectiva da hibridização como elemento constituinte da identidade.

\section{Identidade, Binaridade e Hibridização}

Os posicionamentos que o professor pré-serviço assume ou é levado a assumir durante o curso de Letras tornam-se importantes na contemporaneidade devido aos rumos que a Educação está tomando. Considerando-se que as tecnologias estão fazendo com que o conhecimento seja distribuído por uma rede interconectada de pessoas, a sala de aula parece um campo estático, sem vida, dentro da qual os professores tentam transmitir algo que o aluno sabe onde encontrar sem que a sala de aula se faça necessária. Num mundo extremamente tecnológico e em constante mudança, o aluno-professor também é afetado em relação a sua formação e identidade. Assim, torna-se relevante discutir o posicionamento que o aluno-professor ocupa ou é lavado a ocupar, bem como as possíveis implicações deste posicionamento no contexto educacional. Paulo Freire (1987) nos alerta que ensinar não é transmitir conteúdos e, ao afirmar isso, posiciona professores e alunos em lugares diferentes do que eles têm ocupado: é a partir de um desses lugares que a condição de aluno-professor de língua inglesa está sendo problematizada aqui.

Paulo Freire deixa muito claro que "[...] formar é muito mais do que puramente treinar o educando" (2000, p. 15); diz também que “[...] ensinar não é transferir conhecimento, mas criar as possibilidades para a sua produção ou a sua construção" (Freire, 2000, p. 25). Ao colocar o aluno-professor na posição de quem recebe o conteúdo, de quem se alimenta do saber do docente universitário (este sim tido como distribuidor do conhecimento), constrói-se uma identidade de aluno baseada na perspectiva de que ele (o aluno-professor) não tem condições de construir conhecimento; em decorrência disso, ele deve ser o depositário do conhecimento do outro (em nosso contexto específico, depositário do conhecimento veiculado pelo professor universitário: sim, veiculado porque o professor universitário também não é geralmente visto como construtor de conhecimento - na maioria das vezes ele é tido como um mero porta-voz do conhecimento teórico produzido fora das salas de aula da graduação).

Desta maneira, o aluno-professor forma-se na perspectiva de que precisa ter um domínio de conteúdo amplo para que possa, a seu turno, repassar para o aluno (depositário $d a v e z$ ) o que aprendeu na Universidade, sem que haja uma (re)construção ou apropriação significativa dos sentidos produzidos em relação aos conteúdos memorizados. Tal situação pode fazer o aluno-professor relegar à instituição de ensino, muitas vezes, a tarefa de repassar para ele todos os conhecimentos inerentes à formação de professor, sem que ele (o aluno) questione-se sobre o seu papel e a forma como o conhecimento tem sido tratado. As posi-

674 Educação \& Realidade, Porto Alegre, v. 38, n. 2, p. 669-682, abr./jun. 2013 Disponível em: <http://www.ufrgs.br/edu_realidade> 
ções de depositante do professor universitário e de depositário do aluno universitário entram em conflito no momento do estágio, pois o alunoprofessor divide-se entre ser aluno e aprender tudo para estar pronto, e ser professor sabendo pouco, não estando pronto (raramente se problematizam tais perspectivas em sala de aula, dificilmente se discute com os alunos a possibilidade de alguém ter estado pronto quando começou a lecionar, ou qual seria afinal o sentido de estar pronto).

Na tentativa de assumir posições fixas e imutáveis o conflito se instala: em uma margem, um sujeito-professor supostamente ativo, emissor, depositante; na outra margem, um sujeito-aluno passivo, receptor, depositário. Duas posições tão contraditórias num mesmo indivíduo certamente tornarão a existência do aluno-professor um processo interminável de lutas entre uma identidade e outra, ou pior, o aluno-professor acabará, provavelmente, assumindo apenas uma das identidades, a de um reprodutor das memórias arquivadas, conformando-se com o papel de repassá-las sem questioná-las, sem dar a si mesmo a possibilidade de aprender novos caminhos.

Ao destacar posições tão fixas, de professor transferidor de conteúdos e de aluno receptor de conteúdos, estamos nos reportando a um conceito de identidade como um princípio de oposição, de totalidade (Touraine, 1966 apud Castells, 1999), porém, há outros modos de entender as identidades. Em um destes outros modos, alinhado às teorias pós-coloniais, pensar a identidade (para nós, especialmente a identidade de aluno-professor) constitui-se em percebê-la a partir de (re)posicionamentos constantes. Para melhor compreender esta perspectiva, é preciso discutirmos, antes de mais nada, um pouco sobre as mudanças em torno do conceito de identidade e de como este construto primeiro entrou em crise no pensamento ocidental.

Stuart Hall (2005) chama a atenção para concepções diferentes em torno da identidade. Segundo o referido autor, a intensa movimentação ao redor do conceito de identidade, nos últimos anos, está relacionada ao declínio das velhas identidades que estabilizaram o mundo social e que fizeram surgir novas identidades, fragmentando o indivíduo moderno, até então visto como um sujeito unificado. De acordo com Hall,

\begin{abstract}
[...] um tipo diferente de mudança estrutural está transformando as sociedades modernas no final do séc. XX. Isso está fragmentando as paisagens culturais de classe, gênero, sexualidade, etnia, raça e nacionalidade, que, no passado, nos tinham fornecido sólidas localizações como indivíduos sociais. Estas transformações estão também mudando nossas identidades pessoais abalando a ideia que temos de nós próprios como sujeitos integrados (Hall, 2005, p. 9).
\end{abstract}

Esta suposta perda de nossa também suposta estabilidade faz com que haja um deslocamento ou descentralização do sujeito. Esta situação dupla de acontecimentos faz com que haja um descentramento do 
A Condição de Aluno-Professor de Língua Inglesa em Discussão

que se considerava ser o nosso lugar no mundo social e de nós mesmos, nos conduzindo a uma crise identitária. Para Kobena Mercer (1990 apud Hall, 2005, p. 9) “[...] a identidade só se torna uma questão quando está em crise, quando algo que se supõe fixo, coerente e estável é deslocado pela experiência da dúvida e da incerteza". Embora não se possa afirmar que a identidade do aluno-professor de língua inglesa tenha sido em algum momento da história coerente e fixa, devido às inúmeras dificuldades enfrentadas na formação do professor de língua inglesa, é possível dizer que a condição de aprendiz tem sido reforçada durante muito tempo pela estrutura dos cursos de Letras e pelas pesquisas voltadas para a aquisição de uma língua estrangeira, estudos que colocavam o aluno na posição de aprendiz (posição concebida como binariamente oposta à de professor), ou seja, assujeitado, passivo, receptor. Apesar de buscarem um aprendiz participativo, o modo como o aprendiz é tratado teoricamente, e consequentemente em grande parte das estruturas curriculares, é como alguém que precisa ser ensinado, ou seja, alguém que precisa, por exemplo, receber de um professor as melhores estratégias de aprendizagem e de um currículo os conteúdos necessários para sua formação. Via de regra, não é o aprendiz quem traz para seus estudos aquilo que acredita precisar conhecer, mas sim um grupo de pessoas mais experientes que se arvoram conhecedores das necessidades dos alunos e assim formulam listas de conteúdos e áreas de conhecimento a serem transmitidos e dominados pelos alunos. A educação bancária (Freire, 1987), continua sendo regra nos processos formativos escolares.

Para explicar ao leitor as mudanças em relação ao conceito identidade, utilizo as ideias de Hall (2005; 2009), segundo o qual para falar sobre o sujeito e suas identidades é preciso abordar três concepções. Uma primeira concepção mostra um indivíduo senhor de si, o sujeito do Iluminismo, que se torna o centro, unificado, dotado da capacidade da razão, de consciência e de ação. A segunda concepção aponta um sujeito sociológico, integrante da sociedade tradicional, nem autônomo tampouco autossuficiente, mas formado pela relação com outras pessoas consideradas parte de sua história, pela relação com o mundo social. Este sujeito ainda tem uma essência interior, como nas concepções anteriores, mas constitui-se e transforma-se no contato contínuo com os mundos culturais exteriores e as identidades que esses mundos oferecem. Sujeito e estrutura se complementam. O indivíduo na sociologia, segundo Hall, passou a ser visto como mais localizado e definido no interior das estruturas e das formações que dão suporte a sociedade moderna. Para Hall, existe ainda um terceiro conceito, o do sujeito pós-moderno. Hall afirma que a relação entre sujeito e sociedade tem sido desestabilizada pelo mundo interconectado. Esta desestabilização faz surgir um novo sujeito, o sujeito pós-moderno, o qual passou a ser concebido como estabelecendo relações provisórias, variáveis, sem que tenha identidade fixa, essencial ou permanente. Essa desestabilização do sujeito é tratada por Hall (2005) como consequência dos diferentes acontecimentos que levaram à descentralização do sujeito cartesiano, 
que se deu desde o questionamento das ideias de Descartes e Locke até o feminismo. Este último, por sua vez, problematizou a noção de que homens e mulheres congregariam biologicamente uma mesma identidade, a de seres humanos, e enfatizou a diferença entre os sexos atribuindo um novo sentido à identidade a partir da diferença sexual.

A desestabilização do sujeito com uma identidade fixa reflete-se na sala de aula e na condição de aluno-professor de língua inglesa, pois ao ir além do conceito de identidade como oposição, totalidade, o aluno-professor pode passar a compreender-se ora como aluno e ora como professor durante o seu processo de formação, assim como poderá perceber-se também ora falante da língua materna e ora falante da língua Outra, ora envolvido com discursos que o constituem culturalmente em sua língua materna e ora com os discursos da língua do Outro.

Doce ilusão pensar que isso eliminaria o conflito. Certamente que não. Este novo posicionamento legitima o conflito de estar entre dois (ou mais) posicionamentos diferentes durante a formação, mas não elimina o conflito em conviver com esta multiplicidade de eus. Embora possa levar ao entendimento e autorizar a existência de um tipo de conflito, não deixa de criar outros. A movimentação entre uma identidade e outra permite o estabelecimento de novas formas de ser e entender a si e os outros (futuros alunos). Ser aluno e ser professor, ser falante da língua materna e ser falante da língua Outra, ser cultura materna e a ser a cultura do Outro. É, ao mesmo tempo, não ser nem um nem outro. Ser todos e não ser nenhum. É estar num lugar outro que não o de oposição, um lugar de fronteira, um terceiro espaço (Bhabha, 1998). Confuso? E Freire (2005, p. 149) torna mais complexo, quando escreve

\begin{abstract}
[...] foi exatamente o mundo, como contrário de mim, que disse a mim: você é você; a partir da descoberta de você como não-eu meu, que eu me volto sobre mim e me percebo como eu e, ao mesmo tempo, enquanto eu de mim, eu vivo o tu de você. É exatamente quando o meu eu vira um tu dele, que ele descobre o eu dele. É uma coisa formidável.
\end{abstract}

Para continuarmos nossa incursão dentro das identidades de aluno-professor é necessário falar ainda de mais uma particularidade, a différance derridiana.

Ao falar de uma identidade não fixa, tampouco única, assumese uma visão de identidade como identificação que é construída, que está sempre em processo, nunca acabada (Hall, 2005). Referimo-nos aqui também às significações que construímos para as coisas ao nosso redor, aos sentidos que atribuímos ao conceito de identidade. Se por um lado pensar em identidade tem sido pensar na homogeneidade, na semelhança, naquilo que me torna igual ao outro, naquilo que nos completa, por outro pensar na identidade construída e múltipla é pensar no que me diferencia do outro. Conforme aponta Hall (2009, p. 106) "A identificação é, pois, um processo de articulação, uma suturação, uma 
A Condição de Aluno-Professor de Língua Inglesa em Discussão

sobredeterminação, e não uma subsunção. Há sempre demasiado ou muito pouco - uma sobredeterminação ou uma falta, mas nunca um ajuste completo, uma totalidade". Como todas as práticas da significação, a identidade também está sujeita ao jogo da différance.

Olhar a condição de aluno-professor a partir da différance (Derrida, 2001, p. 33) é perceber que esta condição, assim como a différance de Derrida, “[...] é um jogo sistemático de diferenças, dos rastros de diferenças, do espaçamento, pelo qual os elementos remetem uns aos outros. Esse espaçamento é a produção, ao mesmo tempo ativa e passiva”. Com esta aproximação ao conceito derridiano queremos enfatizar que, na condição de aluno-professor, os rastros de significação do que é ser aluno e do que é ser professor de língua inglesa se fazem pelos rastros de outros significados que constroem a compreensão do que é ser aluno e do que é ser professor. E nisto podemos aproximar Derrida de Bhabha quando este último afirma que “[...] o que interroga a identidade não é simplesmente a imagem da pessoa, mas o lugar discursivo e disciplinar de onde as questões de identidade são estratégica e institucionalmente colocadas" (Bhabha, 1998, p. 81). O significado do que seja um ou outro não é pré-dado. Como signo linguístico, não há uma relação direta entre o significante aluno e o seu significado. O que há são rastros; não há uma relação imediata entre identidade de professor e domínio totalizante do conhecimento, o que há são rastros. Da mesma forma, não há uma relação direta entre ser aluno e apresentar sempre uma resposta positiva de aceitação, não questionadora dos conteúdos repassados, como parecem desejar os construtos em torno da posição de aluno. Essa ideia é construída ao se fazer uma relação direta entre a imagem de aluno e de professor e os seus significados tradicionalmente construídos em determinada cultura. Mas os significados estão sempre em movimento, modificando-se de um momento para outro. Este movimento é o que nos faz chegar ao nosso último tópico, o conceito de hibridismo.

\section{O Aluno-Professor: um posicionamento hibridizado}

Embora correndo o risco de sermos mal interpretadas ao relacionarmos o conceito de hibridismo de Bhabha à condição de aluno-professor, acreditamos ser importante ressaltar esta possibilidade, mesmo que apenas brevemente neste texto. Isto porque percebemos que os elementos ressaltados por Bhabha ao discutir sua noção de hibridismo podem esclarecer questões particulares da condição aluno-professor com que outras teorias parecem não ter se preocupado. Estaremos então embasando esta discussão neste momento especialmente nos conceitos trazidos em O Local da Cultura (1998) e na entrevista Third Space (1990), dada por Bhabha ao entrevistador Rutherford.

Para fazer uso da teoria de Bhabha, na tentativa de tentar explicar a condição de aluno-professor durante o estágio supervisionado, é preciso, antes de mais nada, lembrar que o posicionamento do alunoprofessor durante o estágio é contingente e hierárquico, seja em relação

678 Educação \& Realidade, Porto Alegre, v. 38, n. 2, p. 669-682, abr./jun. 2013 Disponível em: <http://www.ufrgs.br/edu_realidade> 
ao seu lugar de aprendente - subordinado ao professor regente e às hierarquias institucionais, subordinado às escolas (professores regentes, horários) - seja pela relação de poder que a língua inglesa representa no entendimento de que dominá-la é ter a possibilidade de ascender socialmente.

O estar, ao mesmo tempo, no lugar de aluno e de professor de uma língua estrangeira coloca o professor pré-serviço de língua inglesa em um espaço de fronteira, no qual ele precisa negociar, articular o que há de antagônico e contraditório entre as identificações disponíveis a ele. Este lugar de fronteira é também um terceiro espaço, um espaço que permite que aluno e professor encontrem-se num mesmo corpo, transformando a polaridade em elemento produtivo. Nem um nem outro, mas algo diferente dos dois, algo que permite um novo posicionar-se, um terceiro espaço onde a ambiguidade e a binaridade podem ser negociadas. É, portanto, um espaço hibridizado. Não é um espaço livre de conflitos, mas diferentemente do que acontece na situação opositiva da binaridade, no terceiro espaço o conflito torna-se um espaço positivo de negociações, onde os significados não são pré-dados, onde a postura de aluno passivo e professor ativo e a relação com o domínio totalizante da língua estrangeira podem ser questionadas, desafiadas, transformadas. Ao possibilitar esta forma de agência, o terceiro espaço, ao reconhecer o hibridismo como um processo identitário legítimo, torna possível a resistência e a construção de novos caminhos de identificar-se como professor de língua inglesa: agora não mais como um aluno passivo ou um professor ativo, mas como agente motivado a questionar, resistir, propor ou simplesmente permanecer, reconhecendo seu lugar de (re)produtor, desta vez não pela subjugação, mas por um posicionamento consciente e ainda assim possível de ser alterado.

\section{Considerações Finais}

Após esta rápida viagem ao centro do universo chamado estágio curricular, na perspectiva de uma das dificuldades que o envolve, chegamos ao destino com a certeza de que a viagem foi rápida, mas esperamos que tenha sido interessante para o leitor como foi para nós. Sabemos que muitos lugares foram apenas mencionados brevemente, vistos da janela sem que tivéssemos tempo o suficiente para visitálos, e por isso ressaltamos que este texto vai finalizado pela obrigação contextual de fazê-lo, pois nosso desejo era o de continuar esta viagem no fundo interminável. Porém, precisamos concluir, e o fazemos reforçando que o estágio supervisionado em língua inglesa se apresenta para nós como uma arena de conflitos o que não quer dizer que esses conflitos façam deste momento da formação do professor um local de tristezas e perdas; pelo contrário, se percebidos como elementos construtivos, repletos de novas possibilidades de sentidos de si e dos outros, caracterizam-se primeiramente como espaços de crescimento pessoal e 
de construção profissional. Tratar da condição de aluno-professor parecenos crucial para que haja realmente uma possibilidade de intervenção neste momento da formação.

Para propor novas formas de ação é preciso que um dos principais interessados, o professor pré-serviço, entenda o lugar em que está posicionado como um espaço produtivo, justamente por ser híbrido, e, ao invés de responder ao sistema como um sujeito passivo, centralizado, individualizado, afirme-se nas fronteiras de aluno e de professor, perceba-se um agente também híbrido, ativo, múltiplo e coletivamente engajado no contexto social em que está atuando.

Tal entendimento precisa, além disso, permitir ao aluno-professor que se perceba, embora assujeitado ao sistema hierárquico em muitos momentos, também capaz de uma agência construída no processo discursivo, nos momentos e espaços ambivalentes e contingentes que caracterizam a formação do sujeito em geral, e a profissionalização do professor em particular.

Recebido em 03 de outubro de 2011 Aprovado em 05 de julho de 2012

\section{Notas}

1 Os termos estão sendo usados no gerúndio para indicar que aprender e ensinar são processos constantes.

2 Termo utilizado por Jacques Derrida a partir da combinação das palavras francesas différence e defféral para referir-se ao processo de construção de sentidos que, segundo ele, se dá mediante o estabelecimento simultâneo de relações de "diferença" e "adiamento" entre significantes. O termo alude também à relação entre fala e escrita, evidenciando a escrita como espaço diferente da fala, uma vez que em francês a palavra différance, inventada por Derrida, é homônimo perfeito de différence.

\section{Referências}

BARCELOS, Ana Maria; BATISTA, Fernanda de Sá; ANDRADE, Juliane Cristina. Ser Professor de Inglês: crenças, expectativas e dificuldades dos alunos de letras. In: ABRAHÃO, Maria Helena Vieira (Org.). Prática de Ensino de Língua Estrangeira: experiências e reflexões. Campinas: Pontes Editores/ ArteLíngua, 2004. P. 11-29.

BHABHA, Homi. O Local da Cultura. Tradução de Myriam Ávila; Eliana Lourenço de Lima reis; Gláucia Renate Gonçalves. Belo Horizonte: Editora UFMG, 1998.

BRASIL. Ministério da Educação. Proposta de Diretrizes para a Formação Inicial de Professores da Educação Básica em Cursos de Nível Superior. 81 p. 2000. Disponível em: <http://tdx.cat/bitstream/handle/10803/8896/32Apendiceprop ostaformacao.pdf?sequence=25>. Acesso em: 13 out. 2010.

BRASIL. Resoluções CP/CNE 01. Institui as Diretrizes Curriculares Nacionais para a Formação de Professores da Educação Básica, em nível superior, curso 
de licenciatura, de graduação plena. Diário Oficial da [República Federativa do Brasil], Brasília, DF, 9 abr. 2002. Seção I. P. 31.

BRASIL. Resoluções CP/CNE 02. Institui a duração e a carga horária dos cursos de licenciatura, de graduação plena, de formação de professores da Educação Básica em nível superior. Diário Oficial da [República Federativa do Brasil], Brasília, DF, 4 mar. 2002. Seção I. P. 9.

CABRAL-BÜHRER, Édina A. A Prática Reflexiva na Sala de Aula de Estágio Supervisionado em Língua Inglesa. In: VIANA, Vander; MILLER, Inés Kayon de. Caminhos na Formação de Professores de Línguas: conquistas e desafios. In: CONGRESSO LATINO-AMERICANO DE FORMAC̃̃O DE PROFESSORES DE LÍNGUAS (II CLAFPL), 2, 2010, Rio de Janeiro. Anais... Rio de Janeiro: Letra Capital, 2010. P. 534-544

CASTELLS, Manoel. O Poder da Identidade. São Paulo: Paz e Terra, 1999.

CURY, Jamil. Estágio nas Licenciaturas: 300 horas. In: ENCONTRO NACIONAL DE ESTÁGIOS: aspectos Éticos e legais, 1., 1997, Curitiba. Anais... Curitiba: UFPR, 1997. P. 38-50.

DANIEL, Fátima de Gênova. Formação Inicial do Professor de Língua Inglesa: teoria e prática em questão. 2009. Tese (Doutorado em Estudos Linguísticos) Programa de Pós-Graduação em Linguística e Língua Portuguesa, Instituto de Biociências, Letras e Ciências Exatas, Universidade Estadual Paulista Júlio de Mesquita Filho, São José do Rio Preto, São Paulo, 2009.

DERRIDA, Jacques. Posições. Tradução de Tomaz Tadeu da Silva. Belo Horizonte: Autêntica, 2001.

FERNANDES, Vera Lúcia Dias. As Crenças e Práxis de Professores de Língua Inglesa em Formação e o Aprendizado Autônomo. 2005. Tese (Doutorado em Letras) - Programa de Pós-Graduação em Letras, Instituto de Letras, Universidade Federal do Rio Grande do Sul, Porto Alegre, Rio Grande do Sul, 2005.

FREIRE, Paulo. Pedagogia da Autonomia. Saberes Necessários à Prática Educativa. São Paulo: Paz e Terra, 2000.

FREIRE, Paulo. Pedagogia do Oprimido. 17. ed. Rio de Janeiro: Paz e Terra, 1987. FREIRE, Paulo. Pedagogia da Tolerância. São Paulo: UNESP, 2005.

GIL, Glória. Mapeando os Estudos de Formação de Professores de Línguas no Brasil. In: FREIRE, Maximina Maria; ABRAHÃO, Maria Helena Vieira; BARCELOS, Ana Maria Ferreira (Org.). Linguística Aplicada e Contemporaneidade. Campinas: Pontes, 2005. P. 173-182.

GIMENEZ, Telma. As Práticas no Curso de Licenciatura em Letras-Inglês da Universidade Federal de Santa Catarina. In: ABRAHÃO, Maria Helena Vieira (Org.). Prática de Ensino de Língua Estrangeira: experiências e reflexões. Campinas: Pontes Editores/ArteLíngua, 2004. P. 171-187.

HALL, Stuart. A Identidade Cultural na Pós-modernidade. 10. ed. Tradução de Tomaz Tadeu da Silva. Rio de Janeiro: DP\&A, 2005.

HALL, Stuart. Quem Precisa de Identidade? In: SILVA, Tomaz Tadeu da; HALL, Stuart; WOODWARD, Kathryn (Org.). Identidade e Diferença: a perspectiva dos estudos culturais. 9. ed. Petrópolis: Vozes, 2009. P. 103-133.

ORTENZI, Denise Ismênia Bossa Grassano; MATEUS, Eliane Fernandes; REIS, Simone. Alunas Formandas do Curso de Letras Anglo-Portuguesas: escolhas, marcos e expectativas. In: GIMENEZ, Telma (Org.). Trajetórias na Formação de Professoras de Línguas. Londrina: Editora UEL, 2002. P. 143-156.

Educação \& Realidade, Porto Alegre, v. 38, n. 2, p. 669-682, abr./jun. 2013. 
PIMENTA, Selma Garrido; LIMA, Maria Socorro Lucena. Estágio e Docência. São Paulo: Cortez, 2004.

RIGOLON, Paula Simone Tonel. O Trabalho Monográfico: um instrumento mediador da reflexão crítica na formação inicial do professor de língua inglesa. 2006. Tese (Doutorado em Linguística Aplicada e Estudos da Linguagem) - Programa de Pós-Graduação Linguística Aplicada e Estudos da Linguagem, Faculdade de Filosofia, Educação, Letras e Artes, Pontifícia Universidade Católica de São Paulo, São Paulo, São Paulo, 2006.

RODRIGUES, Beatriz Gama. Formação de Professores de Língua Inglesa em um Curso de Letras com Habilitação Única em Inglês. 2007. Tese (Doutorado em Linguística Aplicada e Estudos da Linguagem) - Programa de Pós-Graduação em Linguística Aplicada e Estudos da Linguagem, Faculdade de Filosofia, Educação, Letras e Artes, Pontifícia Universidade Católica de São Paulo, São Paulo, São Paulo, 2007.

RUTHERFORD, Jonathan. The Third Space. Interview with Homi Bhabha. In: RUTHERFORD, Jonathan. Identity: community, culture, difference. London: Lawrence and Wishart, 1990. P. 207-221.

SAVIANI, Dermeval. A Nova Lei da Educação: trajetórias, limites e perspectivas. Campinas: Autores Associados, 1997.

TOURAINE, Alain. La Formation du Sujet. In: CASTELLS, Manoel. O Poder da Identidade. São Paulo: Paz e Terra, 1999.

XAVIER, Rosely Perez. As Práticas no Curso de Licenciatura em Letras-Inglês da Universidade Federal de Santa Catarina. In: ABRAHÃO, Maria Helena Vieira (Org.). Prática de Ensino de Língua Estrangeira: experiências e reflexões. Campinas: Pontes Editores/ ArteLíngua, 2004. P. 153-169.

Clarissa Menezes Jordão é doutora em Letras pela USP, pós-doutora em Globalização e Estudos Culturais no Canadá. Leciona na graduação e pósgraduação (mestrado e doutorado) em Letras na UFPR, em Curitiba/Paraná. Áreas de pesquisa: formação de professores; letramento crítico e multiletramentos; discurso e identidade.

E-mail: clarissamjordao@gmail.com

Édina Aparecida Cabral Bührer é doutora em Letras pela Universidade Federal do Paraná, Curitiba/Paraná. Professora de Língua Inglesa e Estágio Supervisionado com Mestrado em Letras pela UFPR. Instituição de Filiação UNICENTRO. Bolsista da CAPES.

E-mail: ecbuhrer@gmail.com 